buildings." In view of the remarkable showing made by creosoted wooden block pavements in the Baltimore conflagration some years ago as compared with the brick and stone pavements, this statement will be regarded with considerable interest by the wood-preserving industry. The explosion of a piece of creosoted wood is unique. The authors should by all means give us the full details concerning this fascinating phenomenon.

We have not read the rest of the book. Doubtless, it may be quite free from the unfortunate errors which we have noticed in the chapter on coal-tar oils, but in turning the pages we did observe what is evidently only a typographical error on page 33 where the boiling point of water is given as $220^{\circ} \mathrm{F}$.

Too literal interpretation by fire underwriters of these pronouncements may lead them into some interesting arguments with oil chemists.

40 RECTOR ST.

S. R. CHURCH

NEW YORK, N. Y.

February 6, 1922

\section{The International Trade Situation}

The January 7, 1922, issue of The Chemical Age (London) contains an interview with Brigadier General Sir William Alexander on the international trade situation, and especially on British industrial problems in relation to those of other nations. Sir William recently made a tour of the United States and Canada, closely concerned with the future of the dyestuffs industry, and is therefore especially well qualified to speak on this problem.

He points out that though the surplus capacity for dyestuff manufacture, for instance, developed during the war may mean a peace-time war of elimination, Great Britain and America have every chance of pulling through since they are uniquely and satisfactorily placed for all the raw materials, if application and determination be added. Britain can maintain her plants in operation provided that British Empire consumers support their own industries, that her chemists and engineers responsible for running plants concentrate toward maximum efficiency, that labor recognize that maximum production per unit of labor or plant is the greatest security for regular and good wages and low cost of living, that the government continue to assist British industries to fight against depreciated currencies and other handicaps to fair trading on equitable terms, and that the government realize that its consuls and trade commissioners overseas should be competent, commercially, to pioneer, advertise and assist in the development of British trade.

The reconstruction of Europe is all-important to Great Britain as an exporting nation, and no opportunity on the part of such solvent countries as Great Britain and America to assist in reconstruction on sound lines to the extent of such finances as can be safely extended should be missed, but the greatest and most enduring assistance will be in the direction of encouraging poor nations to help themselves. Nations whose currencies have fallen so low as to have little or no purchasing values will require to go hungry until they reorganize their internal economies and industries by producing or taking out of the ground the equivalent of currency to balance imports by exports. $* * * * * *$ Such a policy is the only permanent and reliable method of stabilizing exchanges.

$* * * *$

This doctrine carries little encouragement toward a speedy

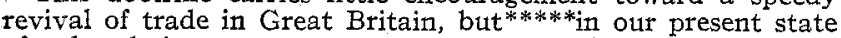
of reduced circumstances we must not trade beyond our means. $* * * *$ We shall retrieve our own prosperity more quickly and surely by concentrated development of trade within the Empire, adding such outside business as exhibits a fair commercial risk, rather than retard reconstruction on normal lines by the encouragement of trading with insolvent nations against phantom credits. $* * * * * *$

America has recovered from the general depression to a greater degree than any other nation because about 80 per cent of her trade is within her own boundaries, because she has nursed and protected her industries.

$$
* * * *
$$

In the peace-time war for commercial supremacy there will be no room for middlemen. Let us make certain that we do not drift into a position of being neither producers or merchants.

Best interests will be served by a trade recovery that is gradual and not spasmodic. The interregnum of restricted trade should be utilized to the fullest extent in perfecting plant, processes, and production efficiencies for all classes of manufactures for which the country is advantageously placed. Chemicals and dyestuffs, with unlimited sources of coal and coal-tar products, limestone, salt, etc., should form two of the most extensive. When reconstruction and reëstablishment of confidence bring demand we should then be in a position to command a fair share of the world's trade against any fair competition.

$$
* * * *
$$

Consultation between manufacturers and close coöperation between employers, and employed should be encouraged to the utmost, with the object of obtaining maximum output, from a minimum of plant, at a minimum cost, and also that we may compete for world trade more collectively as a nation and less as isolated members with no common interests.

\section{The American Potash Industry}

Editor of the Journal of Industrial and Engineering Chemistry:

There is a quite justifiable general opinion opposed to a tariff on any material for protective purposes and particularly opposed to any such protective tariff on a material of which the farmers are to a large extent the ultimate consumers. However, the situation as to the tariff on potash proposed in the bill under consideration, in Paragraphs 75 and 1635 , is such as to make it actually to the financial interest of consumers to have those paragraphs retained in the tariff bill when finally passed.

Except for the periods from 1915 until 1919, and 1919 to date, the production of potash salts has been a German monopoly because the first developed deposits of soluble potash salts were in Germany and the business was so conducted as to keep it under German control by artificial conditions imposed by the German government.

Prior to 1909 this monopoly had maintained high prices of patash salts, around $\$ 38.00$ per ton of 80 per cent muriate. In 1909 the German syndicate was broken for a few months and during that time American interests bought potash mines and under the Schmidtman contracts gave those particular mines the large tonnage of the American market, cutting the price to $\$ 21.00$ per ton of 80 per cent muriate.

With this low price, little more than the cross-country freight on California potash to the eastern United States, the Americanowned German mines made the largest profits in their history.

The re-forming of the German syndicate was followed by the famous German 100 per cent export potash tax applied to product of mines which did not belong to the syndicate or which shipped more than half their product out of Germany; this put the American price higher than it was before. The celebrated Hill-Taft settlement followed, putting the price back to $\$ 38.00$ per ton, and there it stayed until the European war stopped potash coming out of Germany.

Opponents of tariff protection for potash make much of the assertion that, if five years of the sort of embargo that so effectively kept potash out of this country during 1915 to 1919 , with the enormous prices that were paid by consumers, did not establish an American potash industry capable of competing with Germany, certainly the protection provided by the paragraphs in the present bill cannot do so and can result only in that much increased cost to the American consumers, the greatest number of whom are the already sadly overburdened farmers.

A careful analysis of the situation, however, will quickly relieve the mind of the erroneous impression thus given by a casual survey. 
All the forces of the enormous German potash propaganda had been at work for many years in directing as far as possible all search for American potash to the far western regions from which the freight alone across the country would nearly equal the prices at which Germany could lay down potash on our eastern seaboard, and, as was proved by the Schmidtman contracts above referred to, at an enormous profit to German mines if allowed to operate on large production.

The widespread feldspar and greensand potash deposits of the East were prevented from exploitation by the secret forces of the same propaganda frightening proverbially timid capital away from the enormous investments required in plants and machinery for operation of necessary processes to change this insoluble potash to soluble form.

The hidden deposits of soluble potash that must of necessity exist in the salt fields of the eastern United States could not be accidentally discovered as they had been by hundreds of years of shaft and stope mining for rock salt in the salt fields of Germany, for the very good reason that salt mining in the United States has been entirely developed in the last seventy-five years and confined entirely to the purest veins of sodium salt, where there could not of course be any potash, and this same propaganda exploited to the fullest extent the idea that an all-wise Providerice had confined potash deposits to the German salt fields alone.

The European war embargo on German potash therefore found this country totally unprepared to develop quickly any potash production within the limits to which capital could be obtained, except in the salt lakes and deserts of the far West, and only the high prices obtainable justified the costly work of recovery on the comparatively small scale permitted by the limited capital which could be interested. No man who invested a dollar in potash plants during the war period was ever sure of having six months in which to operate without being again subjected to German competition. Consequently investments were made as far as possible with the idea of getting in and getting out quickly with a profit if possible.

After three or four years' record of reasonable profits, some companies actually did get economical operations established, so that with reasonable protection afforded, they can even now produce potash salts at less than double the old German prices.

The exploitation of the several processes for extraction of the insoluble feldspar and greensand potash in the East has gone on slowly and steadily as capital could be secured, and with the protection afforded by the bill in question one plant now almost completed and several more under way will get into operation and will not be hampered by heavy freight from western deposits.

If the present bill had been a law any time before or during the war, American potash production would in less than five years have been on such a scale of magnitude that prices far lower than even the Schmidtman contracts would give handsome profits.

It is a fact well proved by history that whenever American manufacturers are sure of no competition which can have any advantages of foreign cheap labor or foreign government protection, they go into the intensive development of a product on large-scale production with labor-saving mechanical ingenuity that always results in cheapening of that product to a point where foreign competition is left far behind.

With the passage of the bill in question it is a foregone conclusion that capital will be ready and eager to go forward with the developments now so well under way, and in a very short time American quantity production, with the results of the wonderful research work that has been carried out by American chemists for the past five years, will totally destroy Germany's domination of the potash industry of the world. Without this protection, the industry is doomed and German domination will be permanent and complete.

Notwithstanding the fact that the recent German and French potash contracts have been made with American fertilizer companies (three of the principal companies still own large interests in German potash mines), at about the old price (\$37.00 per ton of 80 per cent muriate), the price charged the good old American farmer is $\$ 52.00$ per ton or only a little below the price at which American producers were already offering their American-made potash.

The actual difference to the farmer, therefore, will be but very few dollars and the profit will go to the importer who is sending good American dollars out of this country, instead of to the American mine and factory whose every expense benefits the sadly unemployed ranks of American labor and brains.

136 LIBERTY ST.

H. D. RUHM

NEW YORK, N. Y.

January 20,1922

\section{Fire at Heyden Chemical Plant}

Editor of the Journal of Industrial and Engineering Chemistry:

We have noted in the January issue of the JourNaL a statement with reference to our fire which is grossly exaggerated.

The plant of the Heyden Chemical Company of America, Inc., Garfield, N. J., was visited by a serious fire on the afternoon of December 12, in the refined salicylic acid section. The fire loss, including use and occupancy insurance, is estimated to be between $\$ 550,000$ and $\$ 600,000$.

The conflagration started at $2: 45 \mathrm{P}$. M. in the middle sublimer of a set of three. Two employees were cleaning the hot air chamber. One of them left the chamber and upon returning tripped over a flexible extension cord connected with a properly protected electric light bulb. The lamp fell to the iron grating at the bottom of the hot air chamber, knocking off the guard and breaking the bulb, and the terminal wires came in contact with the iron which caused a short-circuit. The flash ignited the refined salicylic acid in the chamber. The operators endeavored to put out the fire with buckets of water, which failed, and they then closed all dampers, enclosing the flame in the hot air chamber. The sides of the chamber were bulged out by the gas generated from this small fire, which caused the flame to spread instantly to the dust in the room and then to the salicylic acid which had just been removed from the sublimer. The company's fire department had a hose stream playing on the burning sublimer at about the time the dust ignited, which caused a "puff," blowing out the end wall of the building, and the wind carried the flames around the fire protection walls, separating each of the sublimers, and the other sublimers caught fire, causing the destruction of the refined section of the salicylic acid, sodium salicylate and acetylsalicylic acid departments.

The capacity of the destroyed refined salicylic acid section of the plant was approximately $225,000 \mathrm{lbs}$. of U. S. P. acid per month. The crude equipment is intact.

Of the five men who were burned, four of them have reported back at work and the fifth, the foreman who was most seriously burned, it is expected will be discharged from the hospital early in February. The foreman, who was the most seriously burned, received his injuries through his efforts to turn on the valve con-. trolling the carbon dioxide gas, with which all sublimers were equipped to prevent the possibility of serious fire. $\mathrm{He}$ was caught in the "puff" which took place just as he was entering the sublimer room.

\section{F. H. Chamberlain, President}

Heipden Chemical Company of America, ine. GaRfield, N. J. January 18,1922 